\title{
Simulation of the CryoSat-2 satellite radar altimeter sea ice thickness retrieval uncertainty
}

\author{
Rasmus T. Tonboe, Leif Toudal Pedersen, and Christian Haas
}

\begin{abstract}
Although it is well known that radar waves penetrate into snow and sea ice, the exact mechanisms for radar altimeter scattering and its link to the depth of the effective scattering surface from sea ice are not well known. Previously proposed mechanisms linked the snow-ice interface, i.e., the dominating scattering horizon, directly with the depth of the effective scattering surface. However, simulations using a multilayer radar scattering model show that the effective scattering surface is affected by snow-cover and ice properties. With the coming CryoSat-2 (planned launch in 2010) satellite radar altimeter, it is proposed that sea ice thickness can be derived during winter by measuring its freeboard. In this study we evaluate the radar altimeter sea ice thickness retrieval uncertainty in terms of floe buoyancy, radar penetration, and ice type distribution using both a scattering model and Archimedes' principle. The effect of the snow cover on the floe buoyancy and radar penetration and on the ice cover spatial and temporal variability is assessed from field campaign measurements in the Arctic resulting in ice thickness uncertainties of about $0.3 \mathrm{~m}$ for the snow depth variability and $0.3 \mathrm{~m}$ for the snow density variability. In addition to these well-known uncertainties, we use highresolution RADARSAT synthetic aperture radar (SAR) data to simulate errors due to the variability of the effective scattering surface as a result of the subfootprint spatial backscatter and elevation distribution, sometimes called preferential sampling. In particular, in areas where ridges represent a significant part of the ice volume (e.g., the Lincoln Sea), the average simulated altimeter thickness estimate of $2.68 \mathrm{~m}$ is lower than the real average footprint thickness of $3.85 \mathrm{~m}$, making preferential sampling the single most important error source. This means that the errors are large and yet manageable if the relevant quantities are known a priori. Radar altimeter ice thickness retrieval uncertainties are discussed.
\end{abstract}

Résumé. Bien qu'il soit reconnu que les ondes radar pénètrent dans la neige et la glace de mer, les mécanismes précis de diffusion d'un altimètre radar et son lien avec la profondeur de la section efficace de diffusion à partir de la glace de mer ne sont pas bien connus. Les mécanismes proposés par le passé reliaient l'interface de la neige et de la glace c.-à-d. l'horizon de diffusion dominant, directement avec la profondeur de la section efficace de diffusion. Toutefois, des simulations utilisant un modèle multicouches de diffusion radar montrent que la section efficace de diffusion est affectée par le couvert nival et les propriétés de la glace. Avec l'avènement de l'altimètre radar du satellite CryoSat-2 (lancement prévu en 2010), on estime que l'épaisseur du couvert de glace de mer pourra être dérivée durant l'hiver en mesurant sa hauteur par rapport au niveau de la mer. Dans cette étude, on évalue l'incertitude de l'extraction de l'épaisseur de la glace de mer dérivée des mesures de l'altimètre radar en termes de flottabilité des floes de glace, de pénétration radar et de distribution des types de glace à l'aide d'un modèle de diffusion et du "principe d'Archimède". L'effet du couvert nival sur la flottabilité des floes de glace et la pénétration radar ainsi que sur la variabilité spatiale et temporelle du couvert nival est évalué à partir de mesures acquises lors de campagnes de terrain réalisées dans l'Arctique et qui ont donné des incertitudes d'épaisseur de glace d'environ $0,3 \mathrm{~m}$ pour la variabilité de la profondeur de la neige et de $0,3 \mathrm{~m}$ pour la variabilité de la densité de la neige. En plus de ces incertitudes bien connues, on utilise des données RSO (radar à synthèse d'ouverture) de haute résolution de RADARSAT pour simuler les erreurs dues à la variabilité de la section efficace de diffusion résultant de la rétrodiffusion spatiale au niveau de la sous empreinte et de la distribution de l'altitude appelée parfois échantillonnage préférentiel. En particulier dans les zones où les crêtes représentent une portion significative du volume des glaces (p. ex. dans la Mer de Lincoln), l'estimation simulée moyenne d'épaisseur de glace de 2,68 m obtenue par altimètre est plus faible que l'épaisseur moyenne réelle de 3,85 $\mathrm{m}$ de l'empreinte, ce qui signifie que l'échantillonnage préférentiel représente la source unique d'erreurs la plus importante. Ceci signifie que les erreurs sont considérables bien que supportables à condition que les quantités pertinentes soient connues a priori. En conclusion, on discute des incertitudes de l'extraction de l'épaisseur de la glace obtenue par altimètre radar.

[Traduit par la Rédaction]

Received 20 January 2010. Accepted 30 March 2010. Published on the Web at http://pubservices.nrc-cnrc.ca/cjrs on 10 September 2010.

R.T. Tonboe ${ }^{1}$ and L.T. Pedersen. Danish Meteorological Institute, Lyngbyvej 100, DK-2100 Copenhagen Ø, Denmark.

C. Haas. Department of Earth \& Atmospheric Sciences, 1-26 Earth Sciences Building, University of Alberta, Edmonton, AB T6G 2E3, Canada.

${ }^{1}$ Corresponding author (e-mail: rtt@dmi.dk). 


\section{Introduction}

Variation in sea ice thickness is a significant indicator for climate change (Wadhams, 1990; Rothrock et al., 2003), but its interannual, seasonal, and spatial variability is poorly resolved (McLaren et al., 1992). Therefore, much interest is being paid to alternative methods for monitoring sea ice thickness for climate monitoring, such as satellite radar altimetry on CryoSat-2, launched April 2010 (Laxon et al., 2003; Wingham, 1999; Wingham et al., 2006), and laser altimetry using the Ice, Cloud, and land Elevation Satellite (ICESat) (Kwok et al., 2006; Kwok and Cunningham, 2008; Farrell et al., 2009). The ice thickness is derived from altimeters by multiplying the measured freeboard height by an effective snow-ice density factor (the $K$ factor). The freeboard is the height of the ice floe above the water. It is commonly assumed that radar altimeter signals operating at an electromagnetic frequency of about $13 \mathrm{GHz}$ penetrate to the snow-ice interface. However, for pulse-limited spaceborne radar altimetry, modelling indicates that snow depth and density as well as snow and sea ice surface roughness influence the radar penetration into the snow and ice, even for cold homogeneous snow packs in winter. As a result, the effective scattering surface depth, which is the horizon where the freeboard is measured, can vary as a function of these snow and ice properties (Tonboe et al., 2006a). In addition, snow depth and density and ice density critically affect the floe buoyancy and the chances for estimating sea ice thickness by measuring its freeboard (Rothrock, 1986; Giles et al., 2007). The freeboard height is multiplied by the effective density to estimate the ice thickness for a floe in hydrostatic equilibrium. Actually, the ice floe may not be in hydrostatic equilibrium on a point-by-point basis (Doronin and Kheisin, 1977), and this turns out to have consequences for the height measurements using radar. However, on a floe-to-floe basis, hydrostatic equilibrium logically is a valid assumption. Several ice thickness point measurements are needed to characterize the ice thickness distribution representative of a particular ice-covered region (Rothrock, 1986; Haas, 2003). The mode of the ice thickness distribution represents the dominating thermodynamically grown thickness of level ice. However, the distribution has a tail towards thicker ice, i.e., deformed ice, and the mean may be significantly different from the mode (Haas, 2003). Typical ice thickness distributions from the Fram Strait and the Lincoln Sea are shown in Figure 1.

As the ice freeboard has to be multiplied by about 10 to obtain the thickness, even small errors in the freeboard retrieval lead to large ice thickness estimation errors (Rothrock, 1986). This multiplication factor derived from the effective density is not constant and may vary between different thickness categories, i.e., new ice and multiyear ice, as well as seasonally and regionally (Haas et al., 2006a; Wadhams et al., 1992). Tonboe et al. (2006b) pointed out that the parameters affecting the sea ice freeboard and the radar penetration and ice type distribution are not always

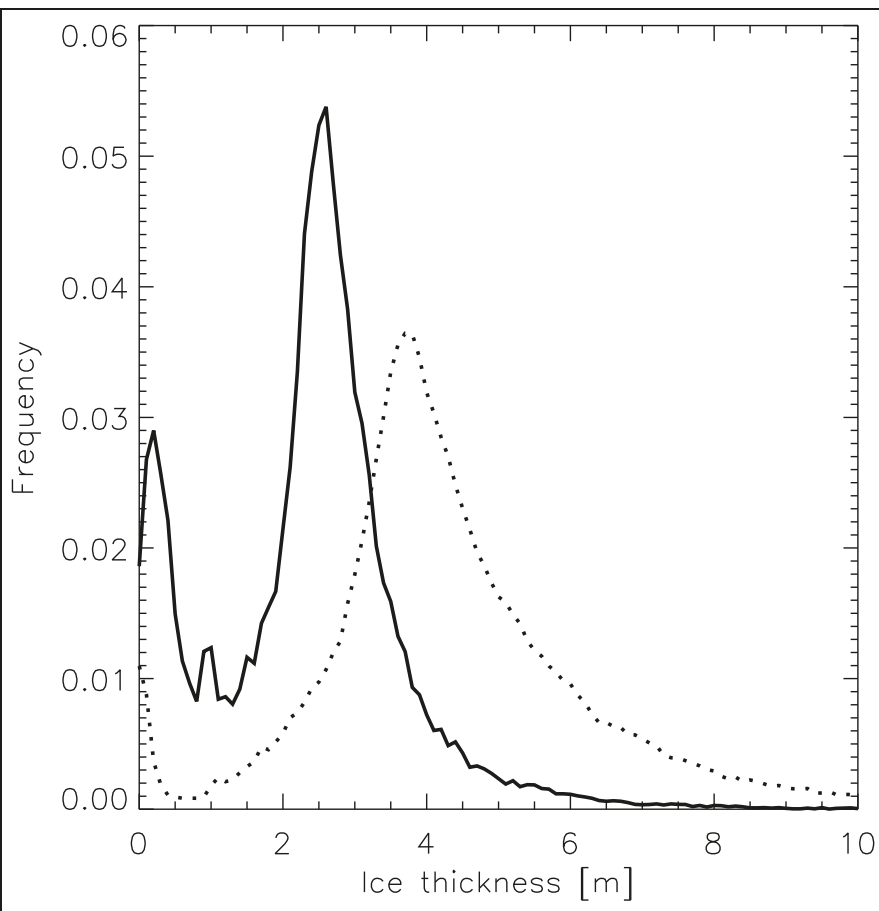

Figure 1. Typical ice thickness distributions measured with a helicopter-borne electromagnetic induction device: Fram Strait, 13 April 2003 (solid line); Lincoln Sea, 12 May 2004 (broken line).

mapped during field campaigns. The error bars on the retrieved ice thickness estimates are needed when the data are assimilated into numerical models or when they are compared with other ice thickness estimates such as those from laser altimeters, submarine sonar, drilling, and electromagnetic induction instruments. It is also important to identify the largest and most important error sources so that these can be assessed during field campaigns and using remote sensing. Rothrock (1986) stated that the uncertainties involved in deriving the ice thickness from its freeboard were too large. However, with the advent of modern spaceborne altimeters, the issue has been revisited. Recent error estimates of the ice thickness retrieval uncertainty for both laser (total error $0.76 \mathrm{~m}$ ) and radar (total error $0.46 \mathrm{~m}$ ) altimeters by Giles et al. (2007) included error sources related to the floe buoyancy, i.e., the snow depth, freeboard estimation uncertainty, and the snow, ice, and water density. The snow depth estimation error resulting in an ice thickness estimation error of $0.1 \mathrm{~m}$ in Giles et al. for the radar altimeter was the most important of the error sources. The error due to radar penetration was assumed negligible in their budget and the error due to systematic height and radar backscatter variability within the footprint is hitherto unexplored. The importance of these two error sources is simulated here using snow and ice measurements and a radar scattering model.

The specific aim of this study is to evaluate the radar altimeter sea ice thickness retrieval uncertainties in terms of both floe buoyancy and radar surface penetration combin- 
ing a radar scattering model with Archimedes' principle (Archimedes (287-212 BC), 1897). The primary sea ice thickness retrieval uncertainties are identified and discussed in relation to the natural variability from field measurements. Further, the altimeter footprint is not a point measurement, and thus the altimeter elevation measurement as a function of subfootprint ice elevation distribution and spatial backscatter intensity distribution is simulated using high-resolution $(50 \mathrm{~m})$ synthetic aperture radar (SAR) data.

\section{Snow and ice data}

In situ data of snow and ice properties in the central Arctic have always been sparse, but to overcome this problem there has been a long history of expeditions. From 1937 to 1991, the Soviet Union operated a series of North Pole drifting stations on multiyear ice floes (Frolov et al., 2006). In addition to the year-round drifting stations, the Sever Project collected snow and ice data at on-ice aircraft landing sites from 1928 to 1989. The Sever data were collected primarily during spring and not during summer melt, i.e., at the end of winter and therefore representing maximum thickness. The measurements were distributed geographically across the Arctic Ocean, but with higher frequency in the eastern Arctic (Figure 2). The National Snow and Ice Data Center (NSIDC) received a subset of the Sever data also including data from the drifting stations (NSIDC, 2004). The data are described in Warren et al.

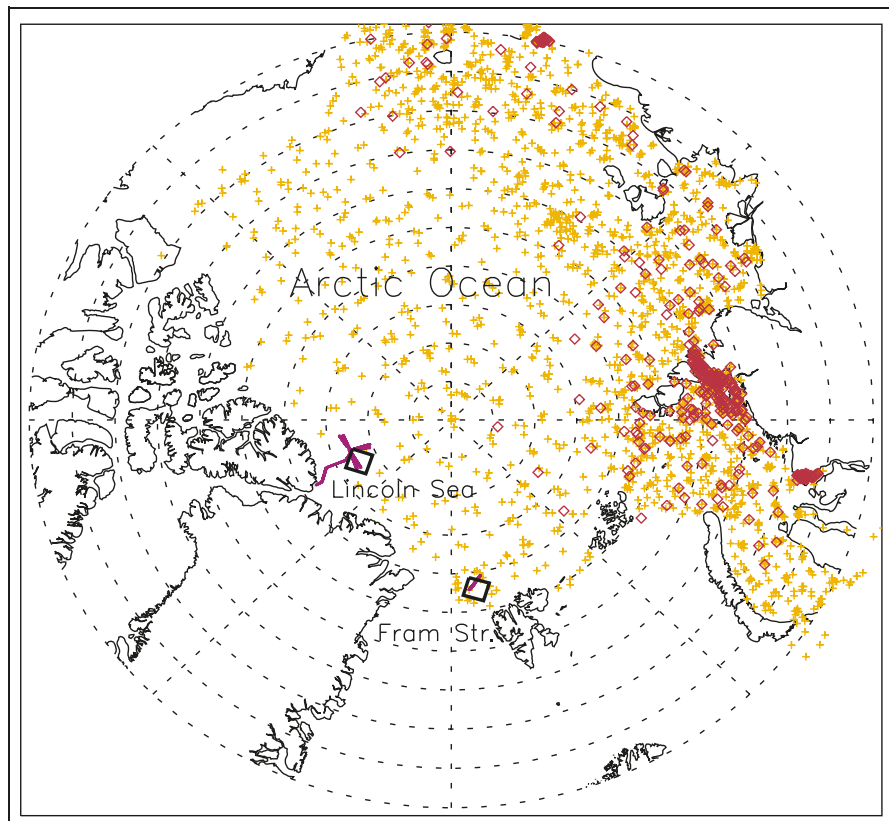

Figure 2. Map of the Arctic Ocean showing the locations of SAR scenes marked with rectangles in Fram Strait and Lincoln Sea. The yellow crosses are Sever snow depth measurements, and the red diamonds Sever snow density measurement locations concentrated in Kara Sea. The purple lines near the SAR frames show the GREENICE ice thickness survey lines.
(1999) and are used here to assess the all-Arctic snow and ice variability.

Furthermore, an extensive field programme directed towards ice thickness monitoring was carried out in the GREENICE project in Fram Strait in April 2003 and in Lincoln Sea in May 2004 (Haas et al., 2006b). These GREENICE activities were almost coincident and overlapping with two SAR scenes used in this study; however, ice drift makes direct comparison difficult. The ice thickness and snow thickness data obtained from both Fram Strait and Lincoln Sea are representative of their respective regions during late winter and spring, and the geographical distribution of these datasets is shown in Figure 2.

The standard mode RADARSAT SAR data classified into the four surface types (in Table 1) are used to prescribe realistic input ice type distributions. The SAR data classification algorithm is based on fuzzy-logic principles. The classification is done by letting an experienced observer identify selected regions visually as belonging to one of the four surface types, and the fuzzy-logic algorithm uses this information to automatically classify the remaining data. The algorithm and method are further described in Gill and Tonboe (2006). The locations of the SAR scenes are shown in Figure 2.

\section{Model description}

The radar scattering model is a multilayer one-dimensional (1D) radiative transfer model where surface scattering is computed at horizontal interfaces (snow surface, icy layers, and ice surface) as described in Tonboe et al. (2006a). Propagation speed, attenuation, and scattering are computed for each layer. The simulated echo delay due to freeboard variations and the time-dependent backscatter intensity recorded onboard the satellite are integrated afterwards in a waveform model suitable for pulse-limited spaceborne altimeters to compute the half-power time, also called the track point. The half-power time is the point in time midway between the onboard satellite received backscatter noise floor and the maximum signal power. The effective scattering surface is the level detected by the halfpower time. On ice sheets, in regions where surface scattering dominates, the half-power time gives a good representation of the mean surface elevation (Davis, 1997). We use the half-power time because surface scattering mechanisms dominate sea ice backscatter. It is a robust

Table 1. Elevation and backscatter values from Fetterer et al. (1992) to be used as a look-up table for the four ice types identified in the SAR scenes, namely new ice, first-year ice, multiyear ice, and ridges.

\begin{tabular}{lllll}
\hline & New ice & First-year ice & Multiyear ice & Ridges \\
\hline Thickness $(\mathrm{m})$ & 0.1 & 1.0 & 3.0 & 10.0 \\
Freeboard $(\mathrm{m})$ & 0.01 & 0.10 & 0.30 & 1.00 \\
Backscatter (dB) & 25 & 20 & 15 & 10 \\
\hline
\end{tabular}


measure of the distance to the effective scattering surface: simulations using seasonal output from a thermodynamic model (snow cover parameters but not surface roughness or ice parameters) as input to the backscatter model show that the scattering surface follows the ice surface within about $5 \mathrm{~cm}$ during winter (Tonboe et al., 2006b). The model concept is different from single-layer scattering models developed for ice sheet backscatter (e.g., Ridley and Partington, 1988), since surface scattering dominates in sea ice, i.e., scattering from the snow and ice surfaces and possibly from layers within the snow.

The forward model uses a set of snow and ice microphysical parameters for each layer to compute the effective scattering surface: temperature, layer thickness, density, correlation length (a measure of the snow grain size or the ice inclusion size), interface roughness, salinity, and snow wetness. The permittivity of dry snow is primarily a function of snow density, and the permittivity of sea ice is primarily a function of salinity and temperature. The permittivity of both materials, $\varepsilon_{\text {eff, }}$ is computed using the mixing formulae for spherical inclusions (Mätzler, 1998):

$\varepsilon_{\text {eff }}=\frac{2 \varepsilon_{1}-\varepsilon_{2}+2 v\left(\varepsilon_{2}-\varepsilon_{1}\right)+\sqrt{\left[2 \varepsilon_{1}-\varepsilon_{2}+3 v\left(\varepsilon_{2}-\varepsilon_{1}\right)\right]^{2}+8 \varepsilon_{1} \varepsilon_{2}}}{4}$

where $v$ is the fraction of volume occupied by inclusions, $\varepsilon_{1}$ is the host permittivity of the material surrounding the inclusions, and $\varepsilon_{2}$ is the permittivity of the inclusions. For snow, $\varepsilon_{1}$ is the permittivity of air $\left(\varepsilon_{\text {air }}=1\right)$, and for saline ice, $\varepsilon_{1}$ is the permittivity of pure ice given in Mätzler et al. (2006). For snow, the inclusions are pure ice, and for saline first-year ice the inclusions are brine pockets. The permittivity and also the volume of brine are given in Ulaby et al. (1986). For multiyear ice, the host material is saline ice and the inclusions are air bubbles.

Surface scattering is the scattering at dielectric interfaces such as the air-snow and snow-ice interfaces. The nadirlooking surface backscatter, $\sigma^{\text {surf }}$, is a function of the nadir reflection coefficient $|R(0)|$ and the flat-patch area $F$ (Fetterer et al., 1992), i.e.,

$\sigma^{\text {surf }}=0.9 F|R(0)|^{2} \frac{H}{u \tau}$

where $H$ is the satellite height; $u$ the pulse propagation speed (speed of light in air, snow, and ice); $\tau$ is the pulse length; and $F$ is the flat-patch area, which is inversely related to roughness (i.e., smooth surfaces have high $F$ ). This model assumes that the signal is dominated by reflection processes from relatively small plane areas (flat patches) normal to the incident signal within the footprint. In the review of different surface scattering models in Fetterer et al. (1992), the approach in Equation (2) is believed to be "more realistic" than those of other models. The geometrical optics model, which is an alternative to Equation (2), makes very similar predictions. The basic concept for all surface scattering models is that the backscatter is a function of the reflection coefficient and surface roughness, i.e., when the surface is smooth, the backscatter is high, and when the surface is rough, the backscatter is lower. All models described in Fetterer et al., including Equation (2), make that prediction.

The improved Born approximation, suitable for microwave scattering in a dense medium such as snow, is used to compute the volume scattering coefficient, $\sigma^{\mathrm{vol}}$ (Mätzler, 1998; Mätzler and Wiesmann, 1999). Volume scattering is scattering from particles or inclusions within layers, i.e., snow grains within the snow layers and air bubbles and brine pockets within the ice layers.

The improved Born approximation for spherical inclusions is as follows (Mätzler, 1998):

$\sigma^{\mathrm{vol}} \cong \frac{3 p_{\mathrm{ec}}^{3} k^{4}}{32} v(1-v)\left|\frac{\left(\varepsilon_{2}-\varepsilon_{1}\right)\left(2 \varepsilon_{\mathrm{eff}}+\varepsilon_{1}\right)}{2 \varepsilon_{\mathrm{eff}}+\varepsilon_{2}}\right|^{2}$

where $p_{\text {ec }}$ is the correlation length; $k$ is the wave number; $v$ is the volume fraction of scatterers; and $\varepsilon_{1}, \varepsilon_{2}$, and $\varepsilon_{\text {eff }}$ are the permittivity of the background, the scatterers, and the layer, respectively. Volume scattering is an important backscatter mechanism for scatterometers operating at $13 \mathrm{GHz}$ and about $50^{\circ}$ incidence, such as QuikScat SeaWinds. However, the total altimeter backscatter is dominated by surface (or interface) scattering, and in our altimeter simulations volume scattering is insignificant as a backscatter source. This is in agreement with laboratory experiments showing that volume scattering at nadir incidence is insignificant as a backscatter source for snow-covered sea ice (Beaven et al., 1995). Though volume scattering is not a backscatter source, it does increase extinction and to some extent the distribution of backscatter between the snow and the ice surface. This distribution and the snow depth do affect the depth of the effective scattering surface (Tonboe et al., 2006a).

No specific correction is applied for antenna gain or pulse modulation in the characterization of the emitted pulse. We use a geometric description of the footprint area in each layer $i$ as a function of time $t$ from Chelton et al. (2001) for a pulse-limited altimeter:

$A_{i}(t)=\frac{\pi u_{i} t H}{1+H / R_{\mathrm{e}}}-\frac{\pi u_{i}(t-\tau) H}{1+H / R_{\mathrm{e}}}$

where the second term is 0 when $t<\tau, R_{\mathrm{e}}$ is Earth's radius $(6371 \mathrm{~km}), u_{i}$ is the speed of light in the layer, and $H$ is the satellite height $(800 \mathrm{~km})$.

The waveform model integrates the time-dependent backscatter from each scattering horizon. The pulse propagation speed, signal extinction, and backscatter are computed as the pulse penetrates the profile, and each individual contribution is summed with appropriate time delay. The backscattered energy, $E$, measured at the satellite for each model time step $\left(1 \times 10^{-11} \mathrm{~s}\right)$ is the sum of the footprint area, $A_{i}$, multiplied by the layer backscatter 
coefficient, $\sigma_{i}$, i.e.,

$E_{t}=\sum_{i=1}^{n} A_{i} \sigma_{i}$

The layer backscatter coefficient includes volume backscattering, though its magnitude is negligible. The backscatter coefficient from each layer is adjusted for extinction using the radiative transfer approach, i.e.,

$\sigma_{\text {total }}=\left(\sigma_{i}^{\text {surf }}+T_{i}^{2} \sigma_{i}^{\mathrm{vol}}\right) \prod_{i=1}^{n} \frac{1}{L_{i-1}^{2}} T_{i-1}^{2}$

where $L$ is the loss and $T$ is the transmission coefficient, where $L_{0}=T_{0}=1$ for the first layer, and $\sigma^{\mathrm{vol}}$ is the negligible volume backscatter coefficient. The waveform model uses a $10^{-11} \mathrm{~s}$ time step.

\section{Simulation results}

A reference profile in Table $\mathbf{2}$ is used together with measured distributions of snow depth and snow density as input to the model to simulate the radar penetration variability of homogeneous unlayered snow packs during winter. Since both the height of the scattering surface and the floe buoyancy are affected by snow depth and snow density, the scattering model is used together with Archimedes' principle to compute the sensitivity of both simultaneously. The surface roughness affects the height of the scattering surface, and the ice density affects primarily the floe buoyancy. Snow measurements are input to the model in order to translate the natural snow variability to simulated range variability. The waveform model is used separately to investigate the sensitivity of the elevation measurement to subfootprint spatial backscatter and elevation variability. Ice type distributions from two classified SAR scenes are used as input. Fixed surface elevations and backscatter coefficients for four different surface types given in Table $\mathbf{1}$ are used as a look-up table in the simulations.

\section{One-dimensional (1D) sensitivity study of ice density and surface roughness}

Table 2 is a reference for the sensitivity simulation study shown in Figure 3. Each parameter (ice density, ice surface roughness, snow density, and snow depth) is evaluated

Table 2. Physical properties of the reference profile.

\begin{tabular}{llllllll}
\hline $\begin{array}{l}\text { Layer } \\
\text { No. }\end{array}$ & $d(\mathrm{~m})$ & $T\left({ }^{\circ} \mathrm{C}\right)$ & $\begin{array}{l}\text { D } \\
\left(\mathrm{kg} / \mathrm{m}^{3}\right)\end{array}$ & $F(\%)$ & $\begin{array}{l}p_{\mathrm{ec}} \\
(\mathrm{mm})\end{array}$ & $S$ & $\varepsilon$ \\
\hline 1 & 0.20 & -10 & 300 & 0.5 & 0.1 & 0.0 & $1.5+0.0001 i$ \\
2 & 3.50 & -5 & 900 & 0.5 & 0.2 & 3.0 & $3.5+0.06 i$ \\
\hline
\end{tabular}

Note: $d$, layer thickness; $D$, density; $F$, flat-patch area (inversely related to roughness); $p_{\mathrm{ec}}$, correlation length; $S$, salinity; $T$, temperature; $\varepsilon$, permittivity computed with the model. separately, and both buoyancy and radar penetration effects are included. The profile in Table 2 has a snow freeboard of $0.6 \mathrm{~m}$ (water density is $1035 \mathrm{~kg} / \mathrm{m}^{3}$ ). The range over which the parameters are varied is assumed to provide realistic upper and lower bounds.

The density of multiyear ice varies between 720 and $910 \mathrm{~kg} / \mathrm{m}^{3}$, and of first-year ice between 900 and $940 \mathrm{~kg} / \mathrm{m}^{3}$, and densities of the submerged part vary between 900 and $940 \mathrm{~kg} / \mathrm{m}^{3}$ for both ice types. Typical variability of the ice density is between 5 and $10 \mathrm{~kg} / \mathrm{m}^{3}$ (Wadhams et al., 1992). Sea ice density is related to its salinity, temperature, and air bubble volume (Timco and Frederking, 1996; Cox and Weeks, 1983). Increasing ice density makes the ice floe sink, thus extending the range to the snow surface, as well as the apparent ice surface and the scattering surface (Figure 3A). Decreasing ice density raises the snow, ice, and scattering surface, thus shortening the range.

Surface roughness is a central model parameter (Dierking et al., 1997). Using Equation (2), Fetterer et al. (1992) estimate that for realistic backscatter values between 20 and $40 \mathrm{~dB}$ the flat-patch area is between $0.2 \%$ and $16.0 \%$. Some ice types such as multiyear ice (10-20 dB) and deformed ice (10 dB) have even lower backscatter values. Following the reasoning from Fetterer et al., this means that the flat-patch area could be as low as $0.02 \%$. The snow surface roughness (flat-patch area) shown in Figure 3B does not affect floe buoyancy, but instead affects the vertical distribution of backscattering between the snow and the ice surface and thus the effective scattering surface. There is more backscatter from a smoother snow surface (see Equation (20), and thus the effective scattering surface is lifted, shortening the range. It is not known how the snow-ice interface roughness varies in time and space. Therefore it is difficult to assess the importance of this parameter for the effective scattering surface. However, surface roughness is the primary factor affecting the subfootprint spatial backscatter variability, which is discussed in the section titled Simulation of preferential sampling using SAR data.

\section{Effect of snow depth and density using measured distributions}

The climatology of snow cover on sea ice measured at Russian drift stations is described in Warren et al. (1999): the mean Arctic Ocean snow depth increases during the cold season (September to June) from zero to about $34 \mathrm{~cm}$. The maximum snow depth (46 cm in June) is in the Lincoln Sea, and there are local minima north of Siberia and Alaska. The mean snow density increases from $250 \mathrm{~kg} / \mathrm{m}^{3}$ in September to $320 \mathrm{~kg} / \mathrm{m}^{3}$ in May, and regional variations are small (about $25 \mathrm{~kg} / \mathrm{m}^{3}$ in May).

Deeper snow on sea ice (Figure 3C) suppresses the ice surface and raises the snow surface. The scattering surface is not suppressed as much as the ice surface. The result is a range extension for deeper snow. The snow depth distributions from the GREENICE experiments and the Sever project are shown in Figure 4. The snow depth records are 

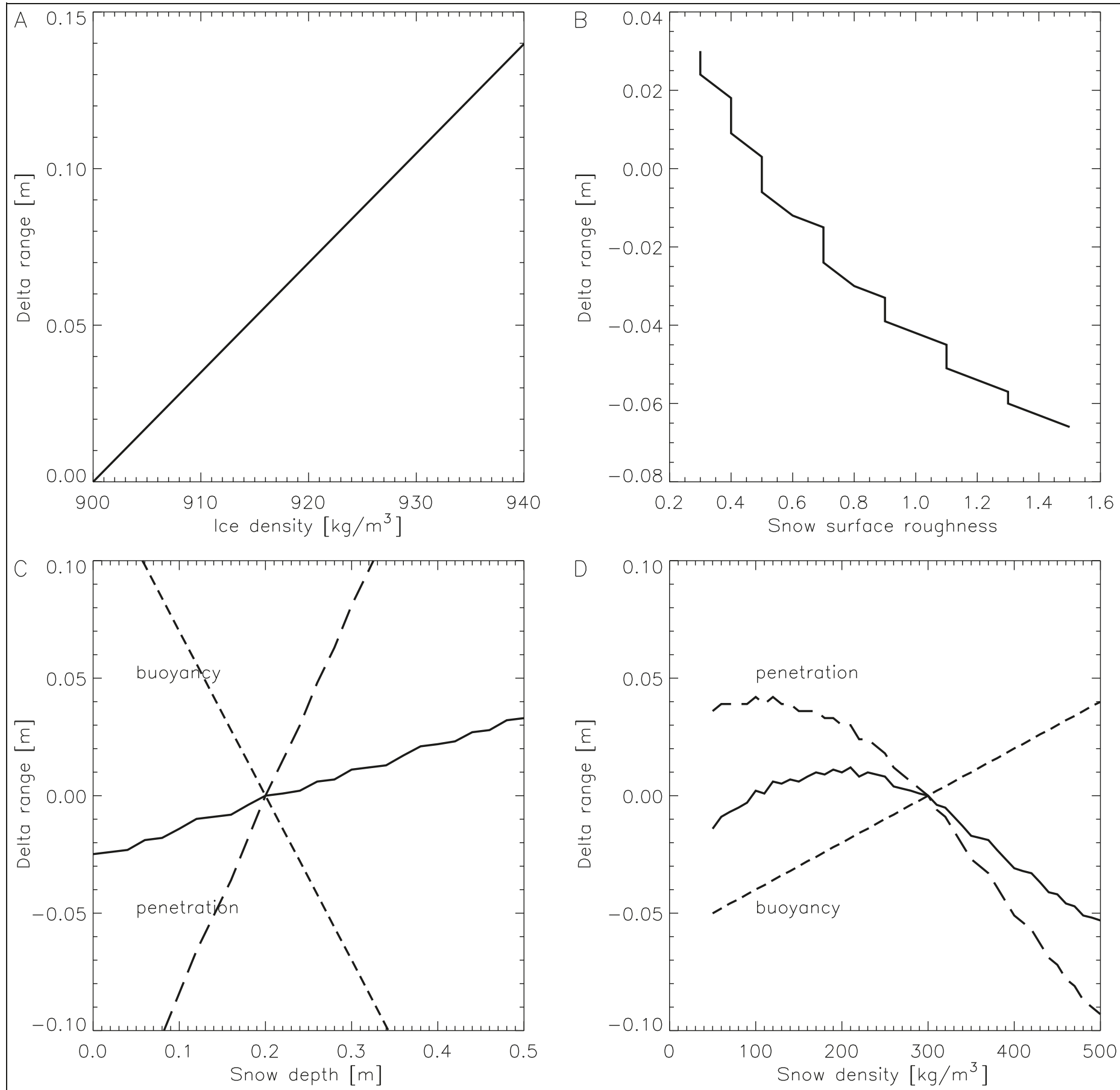

Figure 3. Sensitivity of simulated altimeter range to variability of four ice and snow parameters: (A) sensitivity to ice density; (B) sensitivity to surface roughness represented by flat-patch area in percent; (C) sensitivity to snow depth; (D) sensitivity to snow density. The reference profile is given in Table 2. The ice density variability does not affect the depth of the scattering surface, and the surface roughness does not affect the floe buoyancy (measured from the height of the snow surface). The snow density and snow depth affect both buoyancy and scattering surface depth. The scattering surface depth is shown with the dashed line, and the buoyancy with the dotted line. The resulting combined buoyancy and penetration range change is shown with the solid line. The small-scale oscillations are due to numerical rounding errors in the model.

input to the model, replacing the snow thickness value in Table 2. In the computations this comprises both radar penetration and profile buoyancy for the range of measured values. The range variability due to the snow thickness distribution is shown in Figure 5. The differences in simulated range variability in Figure 5 between the multiyear-all-Arctic Sever data and the regional GREENICE datasets are small. The standard deviation of the range 


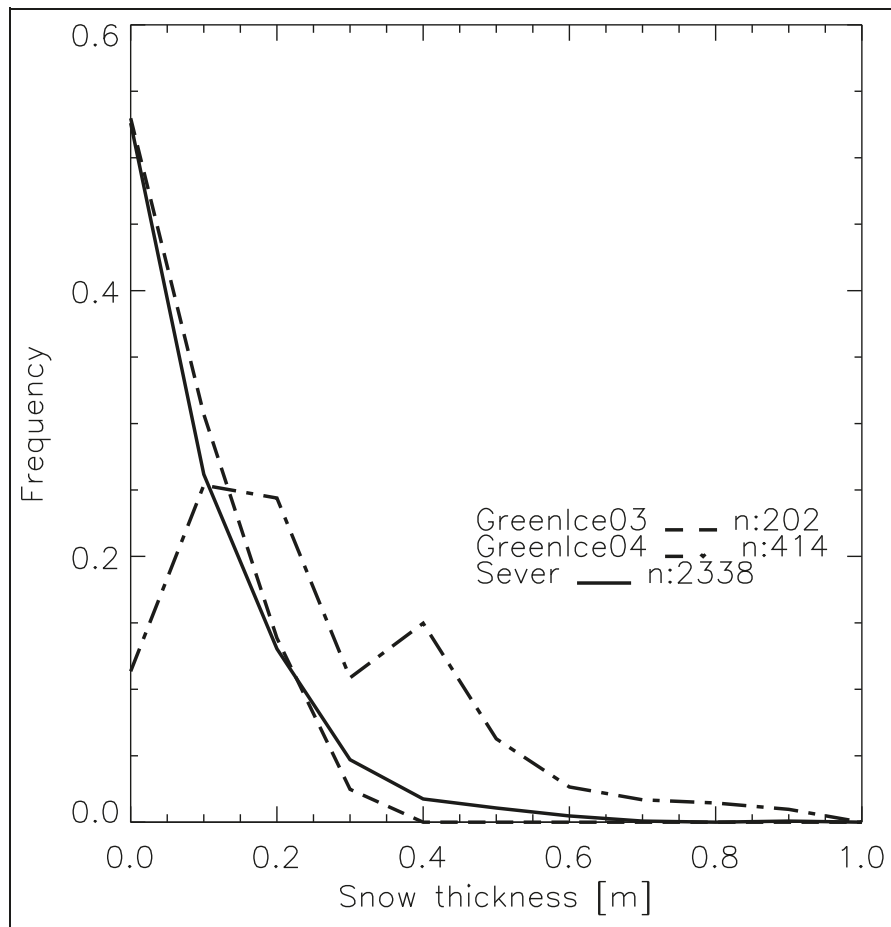

Figure 4. Various measured snow thickness distributions. The solid line shows Sever measurements between 1959 and 1988, primarily for March, April, and May. The dashed line and the dashed-dotted line show the GREENICE measurements in April 2003 and May 2004. The measurement locations are shown in Figure 2.

using the different measured datasets as input to the model is between 1 and $4 \mathrm{~cm}$, with a total range variability of about $6 \mathrm{~cm}$.

Snow density affects the buoyancy (dashed line in Figure 3D) and the reflection coefficient at both the snow and ice surfaces, hence also the distribution of backscatter (see Equation (2)). The scattering surface is therefore lifted for greater snow density (the dash-dot line in Figure 3D). The result is a slightly shorter range for densities above $300 \mathrm{~kg} / \mathrm{m}^{3}$. Measured snow densities from the Sever project are then used as input with the other values from Table $\mathbf{2}$ in the model, computing both radar penetration and profile buoyancy. The range of measured snow densities is shown in Figure 6, with a median of $330 \mathrm{~kg} / \mathrm{m}^{3}$ and values between 170 and $460 \mathrm{~kg} / \mathrm{m}^{3}$. The simulated range variability is shown in Figure 7 for two different snow thickness values, namely $0.2 \mathrm{~m}$, as in Table 2 , and $0.3 \mathrm{~m}$. The simulated range standard deviation using the measured data input is $1 \mathrm{~cm}$ and $2 \mathrm{~cm}$, respectively, with a total range of variability of about $6-8 \mathrm{~cm}$.

\section{Effect of two ice types within the footprint}

High backscatter from limited smooth areas within the footprint can dominate the total altimeter backscatter coefficient and the height of the effective scattering surface

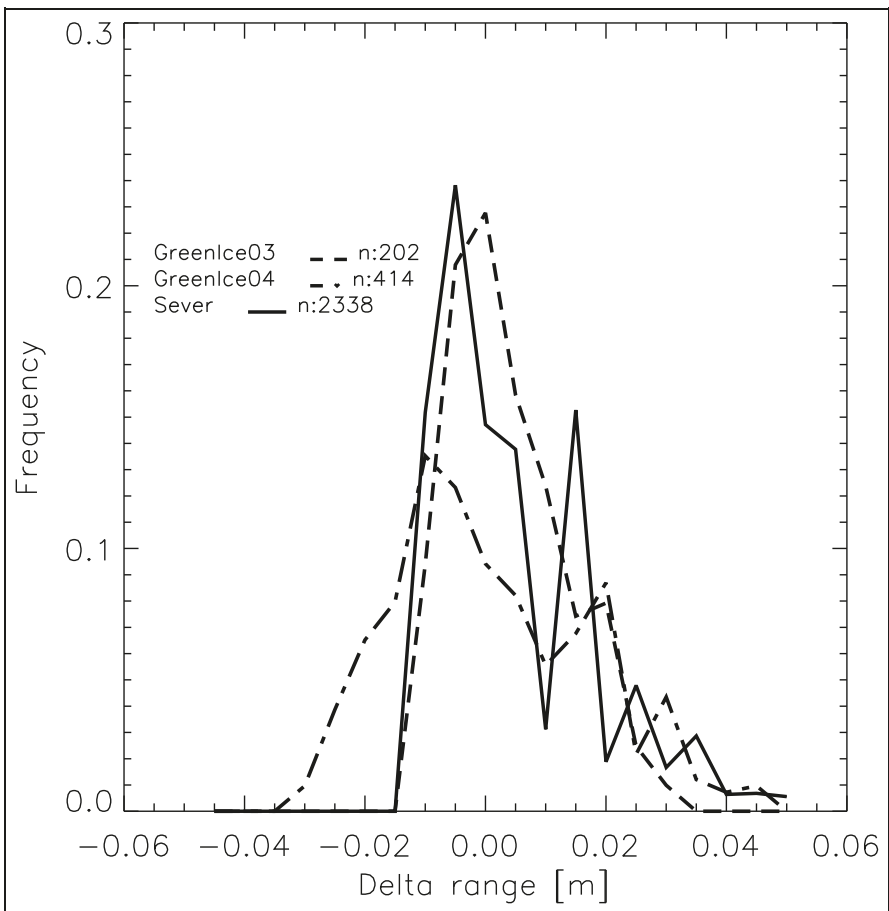

Figure 5. Simulated range variability using measured snow depth from Figure $\mathbf{4}$ and the other values from Table $\mathbf{2}$ as input to the model. The median range is subtracted. The solid line shows the simulated range using Sever measurements, and the dashed and dashed-dotted lines show the simulated range using the GREENICE measurements. Deeper snow gives longer range (see Figure 3C).

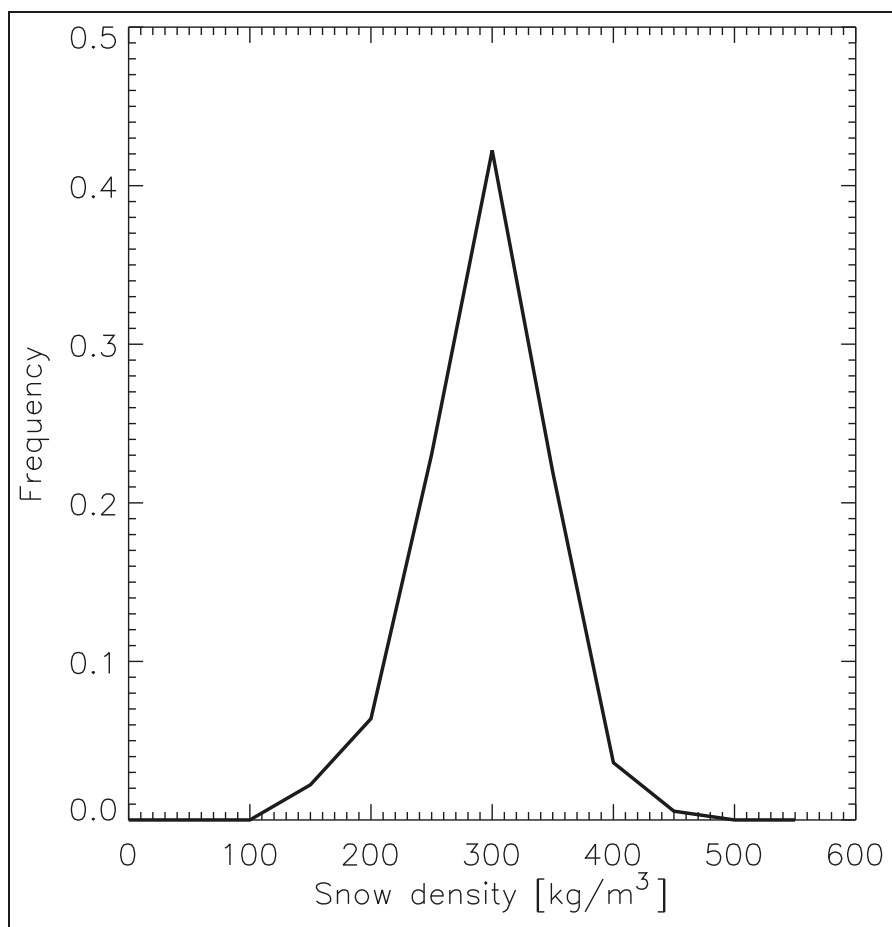

Figure 6. Snow density distribution from Sever measurements between 1959 and 1971, primarily for March, April, and May. 


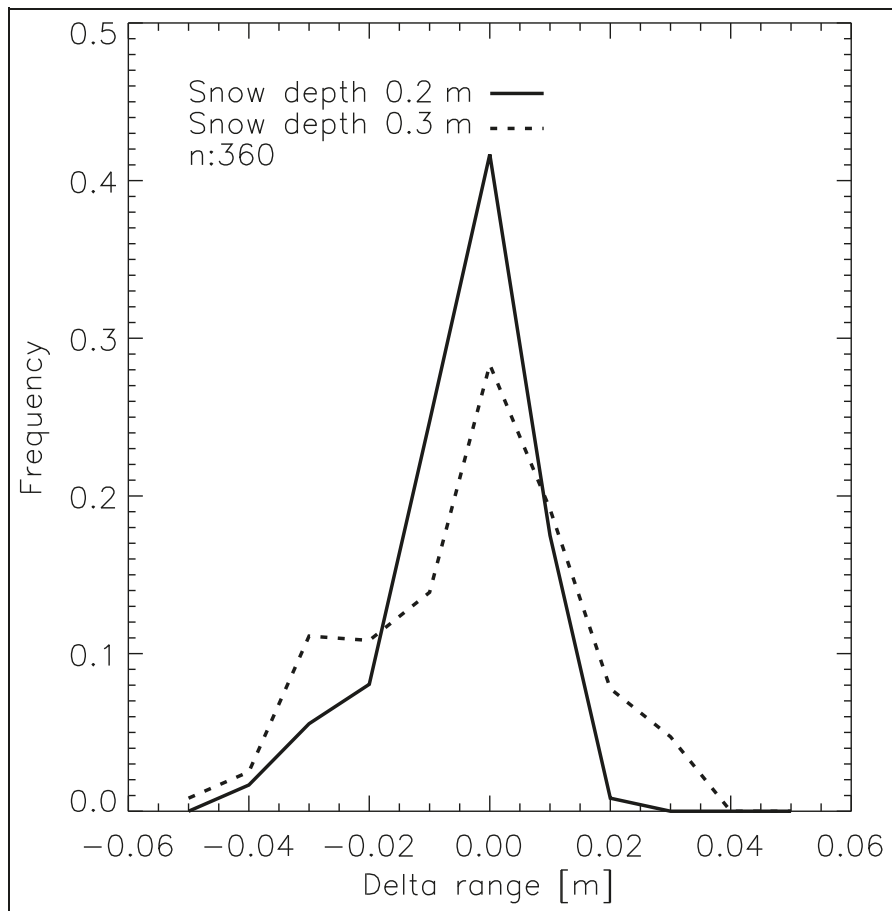

Figure 7. Simulated range variability using Sever snow density measurements shown in Figure 6 and other values from Table 2 as input to the model. The solid line shows the simulated range with $0.2 \mathrm{~m}$ snow as in Table 2 , and the dotted line is for $0.3 \mathrm{~m}$ snow.

because the backscatter is a nonlinear function of the surface roughness (Fetterer et al., 1992).

The results of a simulation experiment are shown in Figure 8. Multiyear ice, $3 \mathrm{~m}$ thick, is mixed with new ice, $0.1 \mathrm{~m}$ thick (see Table 1). The footprint is totally ice covered with these two types, and each type is in hydrostatic equilibrium. It is assumed that when only one ice type covers the entire footprint, its elevation and thickness can be estimated perfectly with the altimeter half-power time. The backscatter coefficient is $15 \mathrm{~dB}$ for the multiyear ice and 10 times higher for the new ice: $25 \mathrm{~dB}$, mainly due to the difference in surface roughness (Fetterer et al., 1992). For a $99 \%$ multiyear ice cover with $1 \%$ new ice, the simulated altimeter ice thickness is underestimated by $26 \mathrm{~cm}$ compared with the average ice thickness. The simulated backscatter coefficient of this mixture is $15.4 \mathrm{~dB}$ compared with $15 \mathrm{~dB}$ for multiyear ice and $25 \mathrm{~dB}$ for new ice.

\section{Simulation of preferential sampling using SAR data}

SAR scenes were analysed in the two different ice regimes in Fram Strait and Lincoln Sea (Gill and Tonboe, 2006). A map is shown in Figure 2. Figures 9A and $\mathbf{9 B}$ are typical scenes for each of the regions. In situ observations during the GREENICE field activities within the frame of both scenes in 2003 and 2004 at the time of acquisition indicate that the classification is realistic. Figure $9 \mathrm{~A}$ shows the distribution of ice types in Lincoln Sea in May 2004. The ice

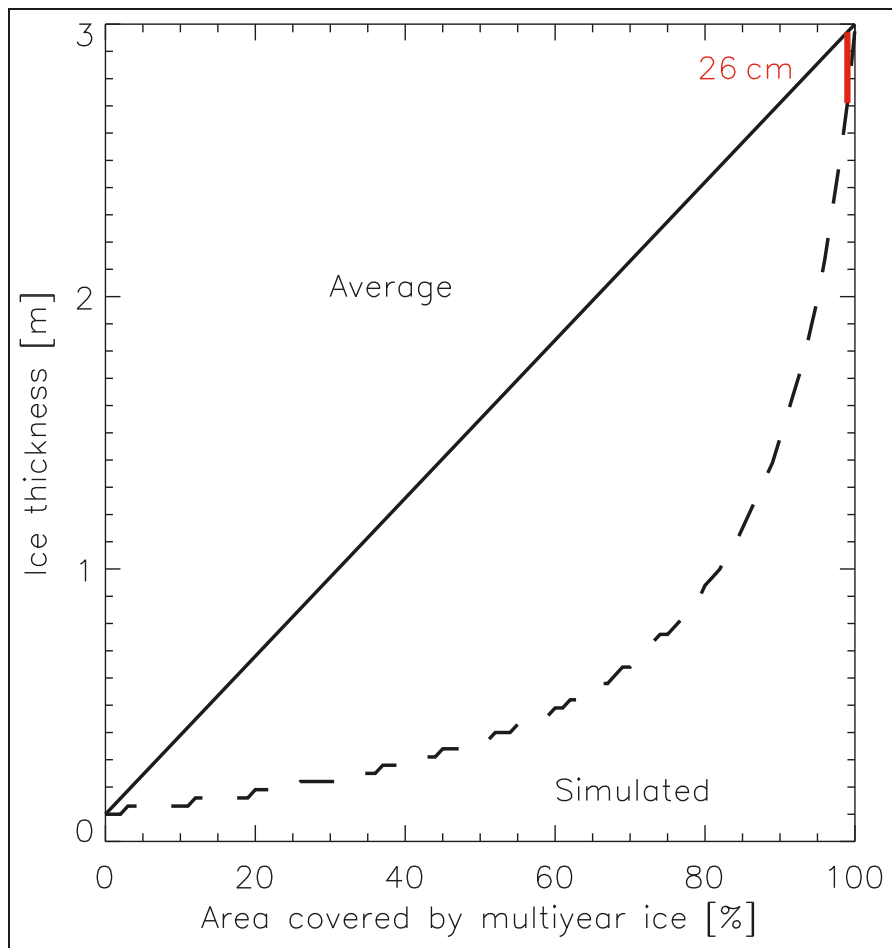

Figure 8. Average thickness (solid line) and simulated altimeter ice thickness using the waveform model (dashed line) for different fractions of new ice and multiyear ice. The footprint is totally ice covered.

cover is complete and dominated by multiyear ice (84.4\%), with fractions of new ice $(1.3 \%)$, first-year ice $(2.9 \%)$, and pressure ridges (11.4\%). Figure 9B shows the distribution of ice types in Fram Strait in April 2003. Also, the ice cover in Fram Strait is complete and dominated by multiyear ice $(63.9 \%)$, with fractions of new-ice $(1.5 \%)$, first-year ice $(33.9 \%)$, and pressure ridges $(0.7 \%)$.

The SAR images are divided into $250 \mathrm{~m} \times 7000 \mathrm{~m}$ altimeter footprints (this size corresponds to the CryoSat sea-ice mode), and these are then used as input to the waveform model. Each of the four ice types is assigned a fixed backscatter coefficient, using values from Fetterer et al. (1992) given in Table 1, and it is further assumed that each type is in hydrostatic equilibrium. The ice thickness for each of the four types roughly corresponds to the modes of the ice thickness distribution measured within the 2003 SAR frame (Haas et al., 2006b). The ice thickness distribution with modes of around 0.1, 1, and $3 \mathrm{~m}$ is shown in Figure 1.

The backscatter and ice thickness look-up-table values are summarised in Table 1. It is assumed that when only one ice type covers the entire footprint its elevation and thickness can be estimated perfectly with the altimeter, as in the example in the previous section (the "retracking" threshold is tuned to the ice surface, and its density is known). Fewer than $0.5 \%$ of the "footprints" in the SAR scenes are covered by just one ice type. Tables $\mathbf{3}$ and $\mathbf{4}$ show the percentage of footprints where only a small fraction $(1 \%, 5 \%$, and $10 \%)$ of the footprint is covered by other ice 


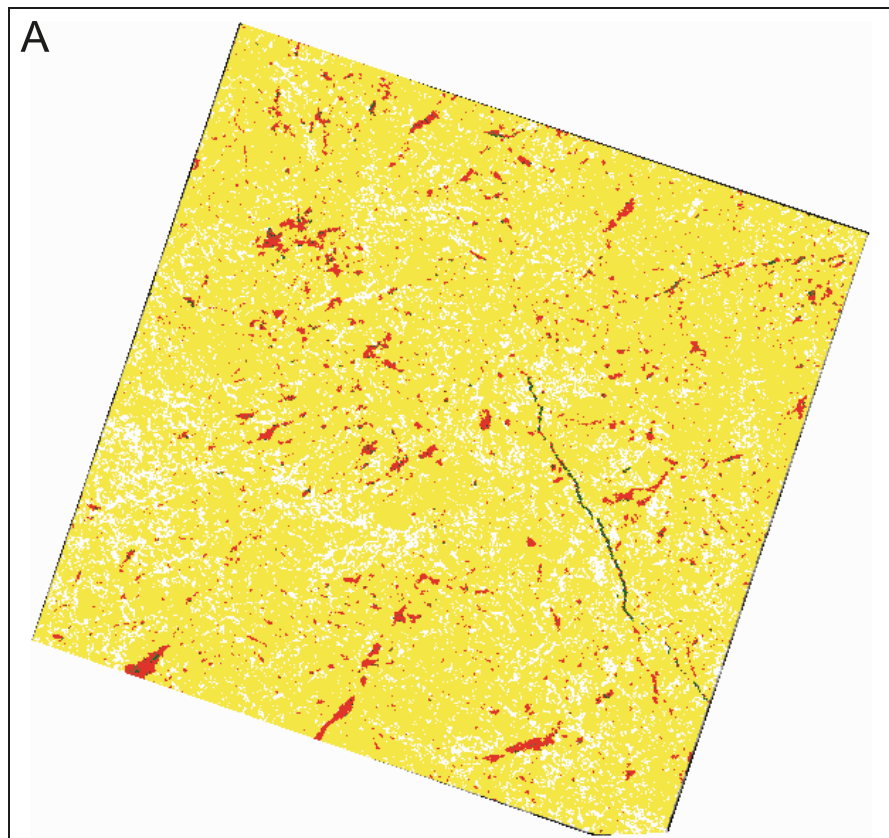

B

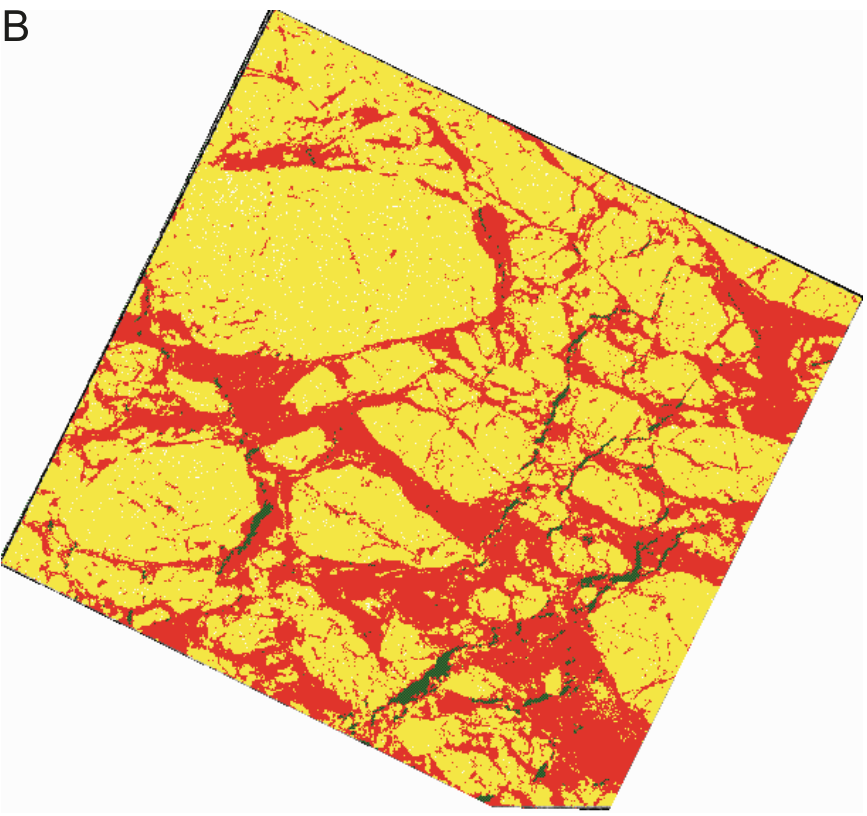

Figure 9. Classification of ice types for 15 May 2004 in Lincoln Sea (A) and 11 April 2003 in Fram Strait (B) based on RADARSAT SAR (standard mode $100 \mathrm{~km} \times 100 \mathrm{~km} ; 50 \mathrm{~m}$ spatial resolution). The positions of the scenes are marked in Figure 2. The ice cover is complete, and yellow is multiyear ice, white is ridges, red is first-year ice, and green is new ice.

types. In Fram Strait (Table 3) there are footprints covered almost entirely by first-year ice or multiyear ice, whereas in Lincoln Sea (Table 4) there are only multiyear ice footprints. Footprints entirely covered by new ice and ridges are not found in the two scenes. The average thickness is computed within each footprint, and the simulated ice thickness is estimated using the waveform model, Table 1, and the footprint ice type distribution in the SAR image. The
Table 3. Footprints $(250 \mathrm{~m} \times 7000 \mathrm{~m})$ within the Fram Strait SAR scene (Figure 9B) dominated by just one surface type (open water, new ice, first-year ice, multiyear ice, or ridges).

\begin{tabular}{llllll}
\hline $\begin{array}{l}\text { Other ice } \\
\text { type }(\%)\end{array}$ & $\begin{array}{l}\text { Open } \\
\text { water }\end{array}$ & $\begin{array}{l}\text { New } \\
\text { ice }\end{array}$ & $\begin{array}{l}\text { First-year } \\
\text { ice }\end{array}$ & $\begin{array}{l}\text { Multiyear } \\
\text { ice }\end{array}$ & Ridges \\
\hline$<1$ & 0 & 0 & 1.4 & 1.5 & 0 \\
$<5$ & 0 & 0 & 3.1 & 13.8 & 0 \\
$<10$ & 0 & 0 & 5.4 & 23.7 & 0 \\
\hline
\end{tabular}

Note: The table shows the percentage of homogeneous footprints that are mixed with $<1 \%,<5 \%$, and $<10 \%$ other surface types.

Table 4. Footprints $(250 \mathrm{~m} \times 7000 \mathrm{~m})$ within the Lincoln Sea SAR scene (Figure 9A) dominated by just one surface type (open water, new ice, first-year ice, multiyear ice, or ridges).

\begin{tabular}{llllll}
\hline $\begin{array}{l}\text { Other ice } \\
\text { type }(\%)\end{array}$ & $\begin{array}{l}\text { Open } \\
\text { water }\end{array}$ & $\begin{array}{l}\text { New } \\
\text { ice }\end{array}$ & $\begin{array}{l}\text { First-year } \\
\text { ice }\end{array}$ & $\begin{array}{l}\text { Multiyear } \\
\text { ice }\end{array}$ & Ridges \\
\hline$<1$ & 0 & 0 & 0 & 0.6 & 0 \\
$<5$ & 0 & 0 & 0 & 7.5 & 0 \\
$<10$ & 0 & 0 & 0 & 25.8 & 0 \\
\hline
\end{tabular}

Note: The table shows the percentage of homogeneous footprints that are mixed with $<1 \%,<5 \%$, and $<10 \%$ of other surface types.

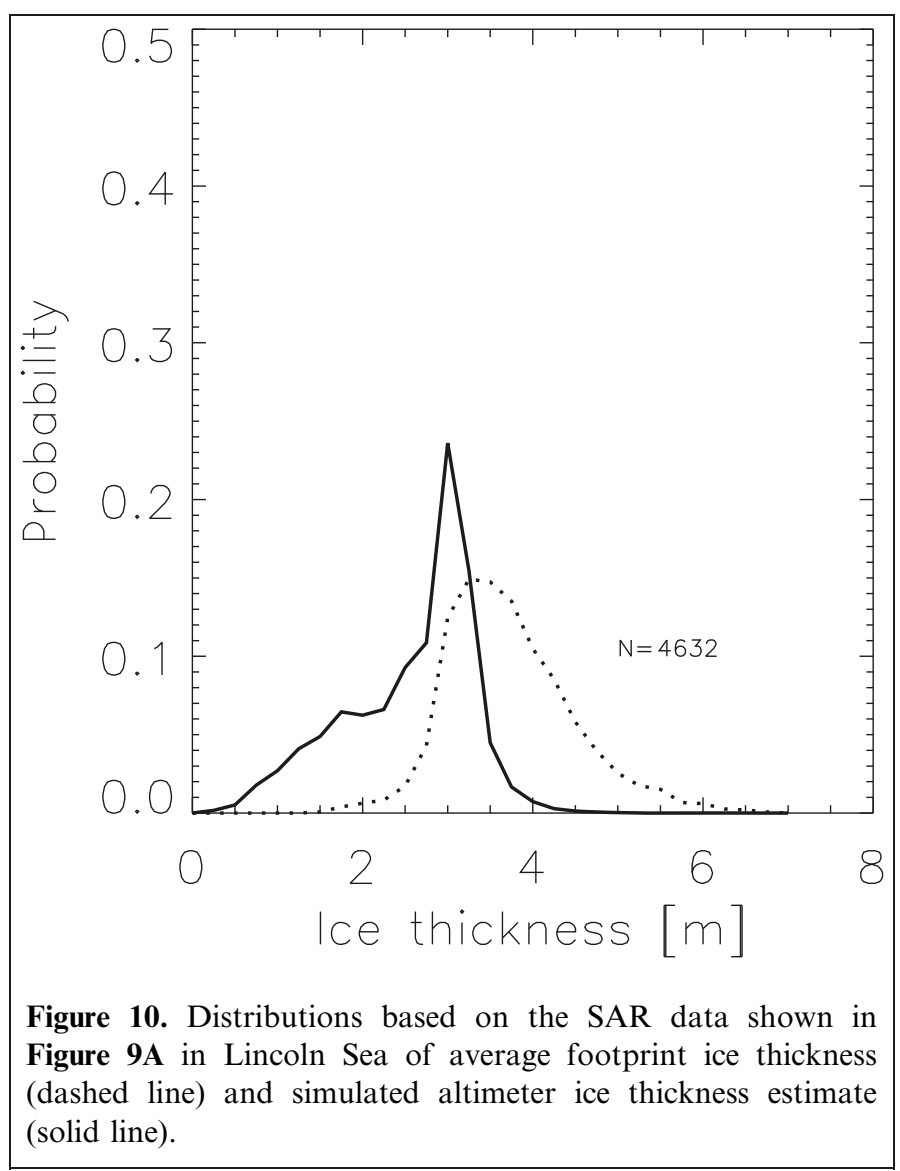

simulated thickness distributions from each scene are shown in Figures 10 and 11. The effects of snow are not included. The measured ice thickness distributions are shown for both Lincoln Sea and Fram Strait in Figure 1. 


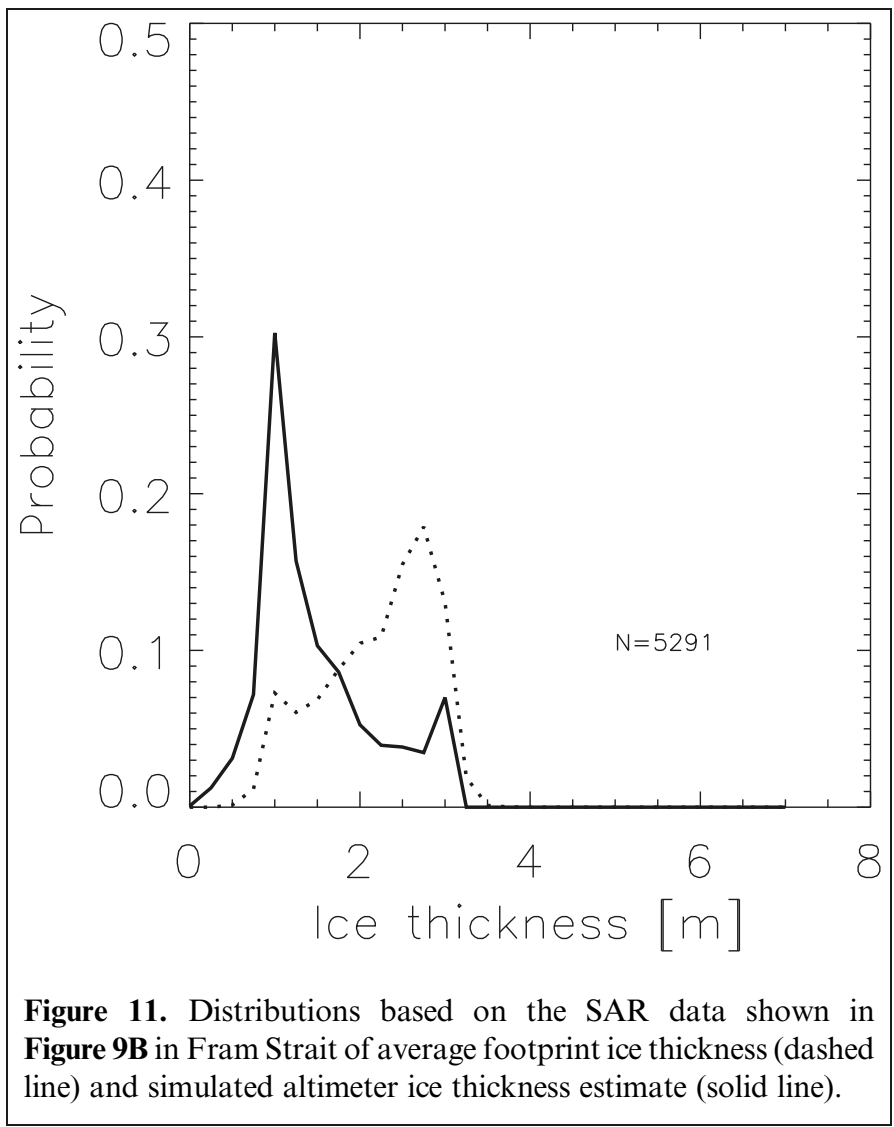

Figures 12A and 12B show that in Lincoln Sea, where the fraction of ridges largely determines the average footprint ice thickness in our simulation, the simulated altimeter ice thickness is much less than the true ice thickness in areas with ridges.

In Fram Strait, shown in Figures 12C and 12D, the simulated altimeter ice thickness is less than the average footprint thickness, particularly in areas with mixed ice types, i.e., multiyear ice, first-year ice, and new ice.

\section{Discussion and conclusions}

It is important to identify the most significant error sources in sea ice thickness retrieval so that these can be monitored and the ice thickness estimates corrected accordingly. Recent estimates of the variability of the snow and ice parameters affecting the floe buoyancy and ice thickness retrieval uncertainty estimates show that four parameters are important, namely snow depth, ice density, freeboard estimation error, and snow density (Giles et al., 2007; Kwok and Cunningham, 2008). The simulations in this study show that the radar penetration variability and the preferential sampling error are error sources that are as important as those affecting the floe buoyancy.

\section{Buoyancy and penetration due to snow depth and density}

Our simulations including both the radar penetration and floe buoyancy show that when snow depth and snow density increase and the ice freeboard (snow-ice interface) is lowered, then the effective scattering surface is raised compared with that for the reference case (Figures $3 \mathrm{C}$ and 3D). This means that the errors due to buoyancy may be partly compensated by radar penetration, and the total error is therefore moderate. Nevertheless, for these two snow parameters it will be important to correct for both buoyancy and radar penetration. Further, using snow and ice climatology for correcting the ice thickness estimate may, on average, reduce the total error, but it introduces an ice thickness estimate bias for any snow cover or ice density deviating from the climatology. Therefore, it will be difficult using climatology to distinguish climate or interannual snow thickness and ice density variability on the one hand from ice thickness anomalies on the other hand.

Layering and vertical variability of snow cover properties are inherent characteristics of natural snow packs and do affect radar scattering. The layering in natural snow packs is formed by individual precipitation events where density is a function of wind speed and temperature during deposition. After deposition, temperature gradient metamorphosis increases grain sizes and compaction, and temporary melt may form icy layers. However, the datasets used here do not include information on the vertical structure of the snow pack.

\section{Spatial variability and preferential sampling}

Figure 8 (average thickness) shows that the high backscatter magnitude from the thinnest ice within the footprint largely determines the elevation of the effective scattering surface. This error source has not been explored in detail. Because of this preferential sampling of the thinner ice types, it will be important to measure just one ice type at a time. In fact, it may be possible to identify echoes from surfaces that are a mix of ice types (Giles et al., 2007). However, nearly all footprints in the two SAR scenes are a mix of different ice types. Because of the limited spatial extent of both new ice and ridges it is not possible to find footprints that are more than $50 \%$ covered by these two types within the two SAR scenes. This may be acceptable for sampling new ice because of its high backscatter, but the ridge freeboard will be significantly underestimated. A significant part of the ice volume is found in ridges (Haas, 2003). In the SAR image from Lincoln Sea, ridges occupy $11 \%$ of the ice-covered area, which is $31 \%$ of the volume assuming thickness values from Table 1. The simulations using the SAR data show that, although the ridges are significant for the average ice thickness, they have low backscatter intensity and are therefore underestimated in the simulated altimeter thickness estimate by the preferential sampling of thinner ice. In Fram Strait, primarily a mixture between level multiyear ice and first-year ice, the average footprint thickness distribution is a mirror image of the simulated altimeter thickness estimate. It thus seems from the simulations that this error can be minimized in 


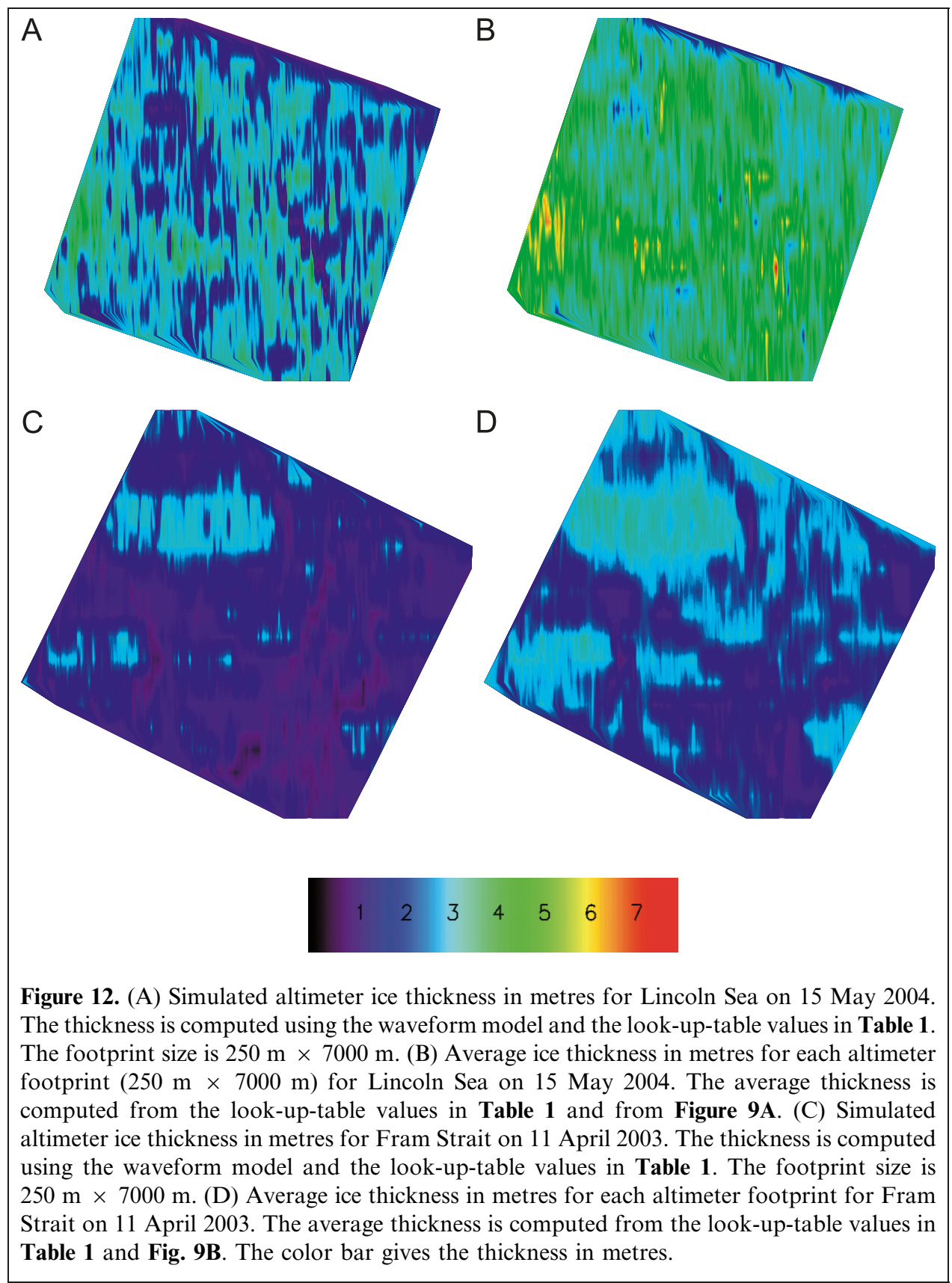

regions where one ice type dominates and where ridges are insignificant for the ice volume.

It is possible that sub-SAR-resolution surface roughness patterns on multiyear ice can have similar effects on the elevation estimate as in the case of different ice types. Whereas refrozen melt ponds typically have smooth surfaces, hummocks have rough surfaces (Onstott, 1992). Hummocks have higher freeboard than refrozen melt ponds and, although this pattern is not resolvable in our SAR data, it represents the same height and backscatter pattern as those of thin and thick ice. Therefore, a multiyear ice floe with deeper refrozen melt ponds may appear thinner than a floe with less deep refrozen melt ponds due to the preferential sampling of the smooth refrozen melt ponds.

\section{Snow and ice parameters relevant for the ice thickness retrieval uncertainty}

Clearly, systematic monitoring is needed for key parameters such as snow thickness and density, ice density, surface roughness, and ice type distribution to distinguish altimeter ice thickness anomalies from the noise introduced by these other parameters. Progress has been made towards mapping snow depth on sea ice using microwave radiometer data. However, the results are still subject to substantial uncertainties due to snow metamorphosis and a mix of different ice types within the sensor field of view (Markus and Cavalieri, 1998).

The subfootprint spatial variability of backscatter intensity and surface elevation creates a bias towards the smooth parts 
of the ice, i.e., new and first-year ice, along with refrozen melt ponds on multiyear ice. This error is dependent on the mixing of surface types within the footprint. The average simulated altimeter and footprint thickness in Figs. $\mathbf{1 0}$ and $\mathbf{1 1}$ are separated by 1.16 and $0.74 \mathrm{~m}$ respectively. However, errors will be greatest in regions where ridges represent a significant part of the ice volume. Spaceborne SAR systems provide means for classifying the ice type distribution as demonstrated in Figure 9. Large-scale ice type distribution mapping is probably our best chance for mitigating the ice thickness uncertainty due to preferential sampling.

Few studies have investigated the variability in sea ice density (Timco and Frederking, 1996). Typical ice density variability of $5-10 \mathrm{~kg} / \mathrm{m}^{3}$ is mentioned in Wadhams et al. (1992), and Timco and Frederking (1996) state that the density can vary between 900 and $940 \mathrm{~kg} / \mathrm{m}^{3}$. The density varies with salinity, temperature, and gas volume, i.e., ice type, which indicates that there can be a systematic variation from region to region. Ice density uncertainty of 5 or $10 \mathrm{~kg} / \mathrm{m}^{3}$ results in uncertainties in the estimated ice thickness of 0.17 or $0.34 \mathrm{~m}$, respectively.

The snow cover affects the buoyancy and effective scattering surface depth. Using snow cover measurements as input to the model, the range in variability is about $6 \mathrm{~cm}$ for both snow depth and density. Multiplying by an effective density and radar penetration factor for the snow and ice system ( $K$ factor) of 5 , this gives an ice thickness variability of $0.3 \mathrm{~m}$ for both parameters. The effective scattering surface depth is thus affected by the snow and ice surface roughness. However, we were not able to find any measurements of surface roughness to account for both ice and snow surface. The simulations for a range of values indicate that the variability in range is about $8 \mathrm{~cm}$, giving an ice thickness error of $0.4 \mathrm{~m}$ with $K=5$.

The European Space Agency CryoSat-2 radar altimeter satellite was launched April 2010 as part of the Earth Explorer programme. Its objectives include the measurement of changes in arctic sea ice thickness during winter. In preparation for the mission, a number of snow and ice parameters were measured during field campaigns. The measured parameters include snow depth, snow density, ice density, and ice thickness, including a comparison of airborne laser and radar altimeter ice thickness measurements with those derived from electromagnetic induction devices. The roughness of both snow and ice surfaces has not been measured, and several of the parameters are not measured systematically by other satellite sensors, e.g., ice density, surface roughness, and the distribution of backscatter and freeboard heights. The future characterization of scattering in natural snow packs requires detailed in situ measurements combined with coincident radar measurements.

\section{Acknowledgements}

This work was supported by the European Union GREENICE (EVK2-2001-00280) and DAMOCLES
(018509) projects. We are grateful for the constructive comments of three anonymous reviewers.

\section{References}

Archimedes. 1897. On floating bodies I. In The works of Archimedes. T.L. Heath. Dover Publications, Inc., New York.

Beaven, S.G., Lockhart, G.L., Gogineni, S.P., Hosseinmostafa, A.R., Jezek, K., Gow, A.J., Perovich, D.K., Fung, A.K., and Tjuatja, S. 1995. Laboratory measurements of radar backscatter from bare and snowcovered saline ice sheets. International Journal of Remote Sensing, Vol. 16, No. 5, pp. 851-876.

Chelton, D.B., Ries, J.C., Haines, B.J., Fu, L.-L., and Callahan, P.S. 2001. Satellite altimetry. In Satellite altimetry and earth sciences. Edited by L.-L. Fu and A. Cazenave. Academic Press, San Diego, Calif. pp. 1-132.

Cox, G.F.N., and Weeks, W.F. 1983. Equations for determining the gas and brine volumes in sea ice samples. Journal of Glaciology, Vol. 29, No. 102, pp. 306-316.

Davis, C. 1997. A robust threshold retracking algorithm for measuring ice sheet surface elevation change from satellite radar altimeters. IEEE Transactions on Geoscience and Remote Sensing, Vol. 35, No. 4, pp. 974 979.

Dierking, W., Carlström, A., and Ulander, L.M.H. 1997. The effect of inhomogeneous roughness on radar backscattering from slightly deformed sea ice. IEEE Transactions on Geoscience and Remote Sensing, Vol. 35, No. 1, pp. 147-159.

Doronin, Y.P., and Kheisin, D.E. 1977. Sea ice. Amerind Publishing Co. Pvt. Ltd., New Delhi, India.

Farrell, S.L., Laxon, S.W., McAdoo, D.C., Yi, D., and Zwally, H.J. 2009. Five years of Arctic sea ice freeboard measurements from the Ice, Cloud and land Elevation Satellite. Journal of Geophysical Research, Vol. 114, C04008. doi:10.1029/2008JC005074.

Fetterer, F.M., Drinkwater, M.R., Jezek, K.C., Laxon, S.W.C., Onstott, R.G., and Ulander, L.M.H. 1992. Sea ice altimetry. In Microwave remote sensing of sea ice. F.D. Carsey. American Geophysical Union, Washington, D.C. Geophysical Monograph 68, pp. 111-135.

Frolov, I E., Gudkovich, Z.M., Radionov, V.F., Shirochkov, A.V., and Timokhov, L.A. 2006. The Arctic Basin: results from the Russian drifting stations. Springer Praxis Books, Berlin, Germany.

Giles, K.A., Laxon, S.W., and Raney, R.K. 2007. Combined airborne laser and radar altimeter measurements over the Fram Strait in May 2002. Remote Sensing of Environment, Vol. 111, pp. 182-194.

Gill, R.S., and Tonboe, R.T. 2006. Classification of GreenICE SAR data using fuzzy screening method. In Arctic sea ice thickness: past, present and future. Edited by P. Wadhams and G. Amanatidis. European Commission, Brussels. Climate Change and Natural Hazards Series 10, EUR 22416, pp. 74-81.

Haas, C. 2003. Dynamics versus thermodynamics: the sea ice thickness distribution. In Sea ice: an introduction to its physics, chemistry, biology and geology. Edited by D.N. Thomas and G.S. Dieckmann. WileyBlackwell, Oxford, U.K. pp. 82-111.

Haas, C., Goebell, S., Hendricks, S., Martin, T., Pfaffling, A., and von Saldern, C. 2006a. Airborne electromagnetic measurements of sea ice thickness: Methods and applications. In Arctic Sea ice thickness: past, present and future. Edited by P. Wadhams and G. Amanatidis. European 
Commission, Brussels. Climate Change and Natural Hazards Series 10, EUR 22416, pp. 136-148.

Haas, C., Hendricks, S., and Doble, M. 2006b. Comparison of the sea ice thickness distribution in the Lincoln Sea and adjacent Arctic Ocean in 2004 and 2005. Annals of Glaciology, Vol. 44, pp. 247-252.

Kwok, R., and Cunningham, G.F. 2008. ICESat over Arctic sea ice: Estimation of snow depth and ice thickness. Journal of Geophysical Research, Vol. 113, C08010. doi:10.1029/2008JC004753.

Kwok, R., Cunningham, G.F., Zwally, H.J., and Yi, D. 2006. ICEsat over Arctic sea ice: Interpretation of altimetric and reflectivity profiles. Journal of Geophysical Research, Vol. 111, C06006. doi:10.1029/ $2005 \mathrm{JC} 003175$

Laxon, S., Peacock, N., and Smith, D. 2003. High interannual variability of sea ice thickness in the Arctic region. Nature (London), Vol. 425, pp. 947-949.

Markus, T., and Cavalieri, D.J. 1998. Snow depth distribution over sea ice in the Southern Ocean from satellite passive microwave data. Antarctic Research Series, Vol. 74, pp. 19-39.

Mätzler, C. 1998. Improved Born approximation for scattering of radiation in a granular medium. Journal of Applied Physics, Vol. 83, pp. 6111-6117.

Mätzler, C., and Wiesmann, A. 1999. Extension of the microwave emission model of layered snowpacks to coarse grained snow. Remote Sensing of Environment, Vol. 70, pp. 317-325.

Mätzler, C., Rosenkranz, P.W., Battaglia, A., and Wigneron, J.P. (Editors) 2006. Thermal microwave radiation - applications for remote sensing. Institute of Engineering Technology (IET), London, U.K. IET Electromagnetic Waves Series 52

McLaren, A.S., Walsh, J.E., Bourke, R.H., Weaver, R.L., and Wittmann, W. 1992. Variability in the sea-ice thickness over the North Pole from 1977 to 1990. Nature (London), Vol. 358, pp. 224-226.

NSIDC. 2004. Morphometric characteristics of ice and snow in the Arctic Basin: aircraft landing observations from the former Soviet Union, 1928 1989. Compiled by I.P. Romanov. National Snow and Ice Data Center (NSIDC), Boulder, Colo. Digital media.

Onstott, R.G. 1992. SAR and scatterometer signatures of sea ice. In Microwave remote sensing of sea ice. Edited by F.D. Carsey. American Geophysical Union, Washington, D.C. Geophysical Monograph 68, pp. 73-104.
Ridley, J.K., and Partington, K.C. 1988. A model of satellite radar altimeter return from ice sheets. International Journal of Remote Sensing, Vol. 9, pp. 601-624.

Rothrock, D.A. 1986. Ice thickness distribution - measurement and theory. In The geophysics of sea ice. Edited by N. Untersteiner. Plenum Press, New York. NATO ASI Series B: Physics,Vol. 146, pp. 551-575.

Rothrock, D.A., Zhang, J., and Yu, Y. 2003. The arctic ice thickness anomaly of the 1990s: A consistent view from observations and models. Journal of Geophysical Research, Vol. 108, 3083. doi:10.1029/ 2001JC001208.

Timco, G.W., and Frederking, R.M.W. 1996. A review of sea ice density. Cold Regions Science and Technology, Vol. 24, pp. 1-6.

Tonboe, R., Andersen, S., and Toudal Pedersen, L. 2006a. Simulation of the $\mathrm{Ku}$-band radar altimeter sea ice effective scattering surface. IEEE Geoscience and Remote Sensing Letters, Vol. 3, pp. 237-240.

Tonboe, R.T., Andersen, S., Gill, R.S., and Toudal Pedersen, L. 2006b. The simulated seasonal variability of the Ku-band radar altimeter effective scattering surface depth in sea ice. In Arctic sea ice thickness: past, present and future. Edited by P. Wadhams and G. Amanatidis. European Commission, Brussels. Climate Change and Natural Hazards Series 10, EUR 22416, pp. 57-63.

Ulaby, F.T., Moore, R.K., and Fung, A.K. 1986. Microwave remote sensing. Active and passive. Vol. 3. From theory to applications. Artech House Inc., Dedham, Mass. pp. 2017-2119.

Wadhams, P. 1990. Evidence for thinning of the Arctic ice cover north of Greenland. Nature (London), Vol. 345, pp. 795-797.

Wadhams, P., Tucker, W.B., III, Krabill, W.B., Swift, R.N., Comiso, J.C., and Davis, N.R. 1992. Relationship between sea ice freeboard and draft in the Arctic basin and implications for sea ice monitoring. Journal of Geophysical Research, Vol. 97, pp. 20 325-20 334.

Warren, S.G., Rigor, I.G., Untersteiner, N., Radionov, V.F., Bryazgin, N.N., Aleksandrov, Y.I., and Colony, R. 1999. Snow depth on arctic sea ice. Journal of Climate, Vol. 12, pp. 1814-1829.

Wingham, D. 1999. The first of the European Space Agency's opportunity missions: CryoSat. Earth Observation Quarterly, Vol. 63, pp. 21-24.

Wingham, D.J., Francis, C.R., and Baker, S. 2006. CryoSat: A mission to determine the fluctuations in Earth's land and marine fields. Advances in Space Research, Vol. 37, pp. 841-871. 